\title{
OPINI AUDIT SEBAGAI PEMODERASI PENGARUH INTELLECTUAL CAPITAL, PROFITABILITAS DAN LEVERAGE TERHADAP NILAI PERUSAHAAN (STUDI EMPIRIS PADA PERUSAHAAN SEKTOR PROPERTI, REAL ESTATE DAN KONTRUKSI BANGUNAN YANG TERDAFTAR DI BURSA EFEK INDONESIA PADA TAHUN 2014-2017)
}

\author{
Oleh : \\ Maria Hendriani \\ Program Studi Akuntansi - STIE DR KHEZ Muttaqien \\ E-mail : mariahendriai@gmail.com \\ DOI Artikel : https://doi.org/10.34308/eqien.v6i2.103
}

\begin{tabular}{|c|c|}
\hline Article Info & Abstract \\
\hline $\begin{array}{l}\text { Article History: } \\
\text { Received } 24 \text { Agustus } 2019 \\
\text { Accepted O2 September } 2019 \\
\text { Available Online 09 September } \\
2019\end{array}$ & $\begin{array}{l}\text { This study aims to determine the effect of intellectual capital, } \\
\text { profitability, and leverage on firm value that is moderated by } \\
\text { audit opinions on property, real estate and building } \\
\text { construction companies listed on the Indonesia Stock Exchange } \\
\text { in 2014-2017. Exogenous variables in this study are } \\
\text { intellectual capital, profitability and leverage. Endogenous } \\
\text { variables in this study are company values, and moderation } \\
\text { variables in this study are audit opinions. The data analysis } \\
\text { technique used in this study is Partial Least Square (PLS). The } \\
\text { results of this study indicate that intellectual capital, } \\
\text { profitability and leverage have no effect on company value, and } \\
\text { audit opinion has a significant effect on firm value, but audit } \\
\text { opinion does not moderate the effect of intellectual capital, } \\
\text { profitability and leverage on firm value }\end{array}$ \\
\hline $\begin{array}{l}\text { Keyword: } \\
\text { Intellectual capital, } \\
\text { Profitability, Leverage, Audit } \\
\text { Opinion, Company Value }\end{array}$ & \\
\hline
\end{tabular}

\section{PENDAHULUAN}

Memaksimalkan nilai perusahaan merupakan Salah satu tujuan utama dari seorang manajer perusahaan. Nilai perusahaan adalah pusat keuangan perusahaan, bagaimanapun, menghitung nilai untuk sebuah perusahaan tidak mudah. Pertama, perusahaan yang berbeda harus dinilai secara berbeda (misalnya, perusahaan publik vs perusahaan swasta). Kedua, nilai perusahaan tergantung juga pada tujuan penilaian, satu perusahaan dapat memiliki beberapa nilai-nilai, tergantung pada metode yang digunakan (Berzkalne \& Zelgalve, 2014).
Banyak perusahaan yang bertujuan mengoptimalkan nilai perusahaannya pada titik maksimum agar dapat mengundang investor untuk berinvestasi, yang mengakibatkan perkembangan pada sektor property, real estate dan konstruksi selalu diikuti persaingan yang ketat antar perusahaan demi tercapainya tujuan dari suatu perusahaan (Saptawani Niasari,2017). Secara umum kinerja sektor property tahun lalu tidak terlalu menggembirakan, dan ini sudah terjadi selama tiga tahun terakhir. Tahun 2017 diharapkan akan menjadi tahun pemulihan akan tetapi belum cukup terbukti dan mendorong 
saham-saham emiten - emiten disektor ini terdepresiasi.

Berdasarkan data dari Bursa Efek Indonesia, sepanjang tahun 2017 indeks sektor property, real estate dan konstruksi bangunan mengalami penurunan sebesar $4,13 \%$ justru pada saat IHSG melonjak sebesar 19,99\%. Meski suku bunga bank Indonesia turun serta kebijakan loan to deposit ratio (LDR) diperlonggar ternyata kinerja sektor property tidak terbukti membaik.

Keberhasilan dalam bisnis didukung dengan teknologi yang berbasis pengetahuan. Berhubungan dengan pengetahuan sebagai sumber daya ekonomi yang penting dalam suatu organisasi, maka intellectual capital memiliki peran penting dalam kemajuan bisnis berbasis pengetahuan. Intellectual capital dapat dikatakan baik jika perusahaan dapat memotivasi karyawannya dalam berinovasi dan dapat meningkatkan produktivitasnya, serta memiliki sistem dan struktur yang dapat mendukung perusahaan dalam mempertahankan bahkan meningkatkan profitabilitas dan nilai perusahaan.

Rasio profitabilitas merupakan salah satu indikator yang sering kali dilihat oleh investor dan merupakan rasio utama. Menurut Brealey, Myers, dan Marcus (2013), nilai pemegang saham tergantung pada putusan berinvestasi yang baik dan operasi usaha yang menguntungkan. Pemegang saham akan tertarik untuk berinvestasi pada perusahaan yang kinerja perusahaannya baik. Kinerja perusahaan dapat digambarkan melalui kemampuan perusahaan dalam mendapatkan keuntungan pada operasi usahanya. Dari keuntungan yang diraih perusahaan dapat dipercaya bahwa keberlangsungan hidup suatu perusahaan pada masa yang akan datang atau bertahan setidaknya satu tahun ke depan untuk mempertahankan perusahaan yang going concern. Rasio profitabilitas sangat berguna bagi para investor sebagai alat pertimbangan untuk mengambil keputusan. Semakin tinggi rasio profitabilitas semakin baik perusahaan dan semakin tinggi juga tingkat return terhadap pemegang saham. Profitabilitas memiliki korelasi positif dengan nilai perusahaan. Rasio profitabilitas yang tinngi merupakan sinyal positif bagi investor dari perusahaan sehingga akan meningkatkan kepercayaan investor serta akan mempermudah manajemen perusahaan untuk menarik modal.
Sumber pendanaan yang dibutuhkan oleh perusahaan dapat diperoleh dari luar perusahaan misalnya melalui pinjaman kepada pihak ketiga, penerbitan saham dan penerbitan obligasi. Perusahaan dapat menggunakan hutang (leverage) untuk memperoleh modal guna mendapatkan keuntungan yang lebih tinggi. Kemampuan perusahaan untuk melunasi kewajibannya baik jangka pendek maupun panjang disebut leverage atau dapat dikatakan bahwa leverage merupakan suatu rasio keuangan yang mengukur seberapa banyak perusahaan dibiayai dengan menggunakan hutang (Wiagustini, 2010:76). Penggunaan hutang yang terlalu banyak tidak baik karena dikhawatirkan akan mengakibatkan penurunan laba yang diperoleh perusahaan sehingga pengelolaan leverage sangatlah penting. Artinya, nilai leverage yang semakin tinggi akan menggambarkan investasi yang dilakukan beresiko besar, sedangkan leverage yang kecil akan menunjukkan investasi yang dilakukan beresiko kecil (Analisa, 2011).

Laporan audit merupakan alat formal yang mengkomunikasikan kesimpulan tentang laporan keuangan audit perusahaan kepada pihak-pihak yang berkepentingan. Opini audit akan menambah tingkat kepercayaan investor terhadap kesesuain informasi keuangan yang disampaikan oleh perusahaan, maka opini audit bisa memperkuat atau memperlemah hubungan antara pengaruh intellectual capital, profitabilitas dan leverage terhadap nilai perusahaan. Perusahaan atau pihak-pihak lain yang berkepentingan membutuhkan informasi laporan keuangan yang sudah diaudit, sehingga pendapat auditor sangat penting.

Gambaran tentang keadaan suatu perusahaan dari sisi akuntansi bisa dilihat dari opini audit yang diberikan oleh auditor independen, sehingga opini audit yang tercantum dalam laporan keuangan bisa digunakan sebagai bahan pertimbangan bagi pihak-pihak yang berkepentingan dalam pengambilan keputusan investasi. Menurut hasil penelitian Phutu Shinta dan I Gst. Ayu (2016), opini auditor sebagai pemoderasi pengaruh good corporate governance pada nilai perusahaan menunjukan hasil positif yang berarti opini audit mampu memoderasi pengaruh good corporate governance pada nilai perusahaan. 


\section{LANDASAN TEORI \\ Nilai Perusahaan}

Menurut Noerirawan (2012), nilai perusahaan merupakan gambaran dari kepercayaan masyarakat terhadap perusahaan yang tercermin dalam proses kegiatan perusahaan selama beberapa tahun, mulai dari usaha tersebut berdiri sampai dengan saat ini sehingga dapat diatikan bahwa nilai perusahaan merupakan kondisi yang sudah dicapai oleh perusahaan sampai dengan saat ini.

\section{Intellectual Capital}

Menurut Gunawan dkk (2013), Intellectual Capital merupakan nilai total dari aset tidak berwujud yang dimiliki badan usaha dan harus dikelola dengan baik untuk memberikan keunggulan kompetitif bagi badan usaha.

\section{Profitabilitas}

Menurut Harahap (2015:304) profitabilitas merupakan rasio untuk mengukur kemampuan perusahaan dalam memperoleh laba dengan menggunakan semua kemampuan dan sumber daya yang ada, seperti kegiatan penjualan, asset, modal, jumlah tenaga kerja, dan sebagainya.

\section{Leverage}

Menurut Harahap (2015:306) untuk menggambarkan hubungan antara hutang perusahaan terhadap modal maupun asset menggunakan penilaian reasio leverage.

\section{Opini Audit}

Dalam Standar Profesional Akuntan (PSA 29), ada lima jenis opini audit, yaitu:

1. Opini Wajar Tanpa Pengecualian (Unqualified Opinion)

Adalah pendapat yang diberikan ketika audit telah dilaksanakan sesuai dengan Standar Auditing (SPAP), auditor tidak menemukan kesalahan material secara keseluruhan laporan keuangan atau tidak terdapat penyimpangan dari prinsip akuntansi yang berlaku (SAK).

2. Opini Wajar Tanpa Pengecualian dengan Paragraf Penjelasan (Modified Unqualified Opinion)

Adalah pendapat yang diberikan ketika suatu keadaan tertentu yang tidak berpengaruh langsung terhadap pendapat wajar.

3. Opini Wajar Dengan Pengecualian (Qualified Opinion)

Adalah pendapat yang diberikan ketika laporan keuangan dikatan wajar dalam hal yang material, tetapi terdapat sesuatu penyimpangan/ kurang lengkap pada pos tertentu, sehingga harus dikecualikan.

4. Opini Tidak Wajar (Adverse Opinion)

Adalah pendapat yang diberikan ketika laporan secara keseluruhan ini dapat terjadi apabila auditor harus memberi tyambahan paragraf untuk menjelaskan ketidakwajaran atas laporan keuangan, disertai dengan dampak dari akibat ketidakwajaran tersebut, pada laporan auditnya.

5. Opini Tidak Memberikan Pendapat (Disclaimer of opinion)

Adalah pendapat yang diberikan ketika ruang lingkup pemeriksaan yang dibatasi, sehingga auditor tidak melaksanakan pemeriksaan sesuai dengan standar auditing yang ditetapkan IAI.

\section{METODOLOGI PENELITIAN Metode Penelitian}

Penelitian ini merupakan jenis penelitian kausal komparatif. Berdasarkan jenis dan teknik pengumpulan data, penelitian ini dikategorikan sebagai penelitian kuantitatif yaitu penelitian yang datanya berbentuk angka-angka. Penelitian ini menggunakan data sekunder. Metode pengumpulan data yang digunakan adalah metode dokumentasi yang memuat kejadian masa lalu/historis (Bambang dan Indriantoro, 2012).

\section{Populasi dan Sampel Penelitian}

Populasi dalam penelitian ini adalah perusahaan sektor properti, real estate dan kontruksi bangunan yang terdaftar di Bursa Efek Indonesia pada tahun 2014-2017. teknik pengambilan sampel dalam penelitian ini adalah purposive sampling dimana cara pengambilan subjek bukan didasarkan pada strata, random atau daerah tetapi didasarkan atas adanya criteria tertentu, untuk itu ditetapkan beberapa sampel berdasarkan kriteria tertentu (Arikunto, 2006:139).

\section{Model Penelitian Inner Model}

Menurut Ghozali (2014 : 30), hubungan antar variable laten berdasarkan pada substantive theory digambarkan dalam Inner model atau model structural. Model persamaannya seperti dibawah ini:

$\eta=\beta_{0}+\beta \eta+r \xi+\zeta$ 
Dimana $\eta$ menggambarkan vector endogen (dependen) variable laten, $\xi$ adalah vector variable laten exogen, dan $\zeta$ adalah vector variable residual (unexplained variance). Akan tetapi PLS didesain untuk model recursive, sehingga hubungan antar variable laten, setiap variable laten dependen $\eta$, atau sering disebut casual chain system dari variable laten dapat dispesifikan sebagai berikut :

$\eta_{\mathrm{j}}=\Sigma_{\mathrm{i}} \beta_{\mathrm{ji}} \eta_{\mathrm{i}}+\Sigma Y_{\mathrm{jb}} \xi_{\mathrm{b}}+\zeta_{\mathrm{i}}$

Dimana $\beta_{\mathrm{ji}}$ dan $\mathrm{Y}_{\mathrm{ji}}$ adalah koefisien jalur yang menghubungkan predictor endogen dan variable laten exogen $\xi$ dan $\eta$ sepanjang range indeks $\mathbf{i}$ dan $\mathbf{b}$, dan $\zeta_{\mathbf{j}}$ adalah inner residual variable.

\section{Outer Model}

Menurut Ghozali, (2014) Outer model atau model pengukuran mendefinisikan bagaimana setiap blok indikatior berhubungan dengan variable latennya. Blok dengan indikator refleksi dapat ditulis persamaannya sebagai berikut :

$\mathrm{X}=\mathrm{Ax} \xi+£ \mathrm{X}$

$\mathrm{Y}=\mathrm{Ay} \eta+£ \mathrm{y}$

(3)

Dimana $\mathrm{X}$ dan $\mathrm{Y}$ adalah indikator atau manifest variable untuk variable laten exogen dan endogen $\xi$ dan $\eta$, sedangkan Ax dan Ay merupakan matrik loading yang menggambarkan koefisien regresi sederhana yang menghubungkan variable laten dengan indikatornya. £x dan £y menggambarkan tingkat kesalahan (error) pengukuran.

Persamaan outer model untuk konstruk formatif dapat disusun sebagai berikut:

$\xi=\prod \xi \mathrm{x}+\delta \xi$

$\eta=\prod \eta \mathrm{y}+\delta \mathrm{y}$

$\xi, \eta, x$ dan y adalah indikator untuk variabel independen, sedangkan $\prod x$ dan koefisien regresi berganda dari variabel laten dan blok indikator $\delta \mathrm{x}$ dan $\delta \mathrm{y}$ adalah tingkat kesalahan pengukuran (residual error).

\section{Weight Relation}

Skor weight relation menunjukkan hubungan nilai varian antar indikator dengan variabel latennya sehingga diasumsikan memiliki nilai mean sama dengan nol (0) dan varian sma dengan satu (1) untuk menghilangkan konstanta dalam persamaan kausalitas. Weight relation dapat disusun dengan persamaan sebagai berikut: $\xi \mathrm{b}=\sum_{\mathrm{xb}} \mathrm{W}_{\mathrm{kb}} \mathrm{X}_{\mathrm{kb}}$

$\eta_{\mathrm{i}}=\sum_{\mathrm{ki}} \mathrm{W}_{\mathrm{ki}} \mathrm{Y}_{\mathrm{ki}}$
$\mathrm{W}_{\mathrm{kb}}$ dan $\mathrm{W}_{\mathrm{ki}}$ adalah bobot $\mathrm{k}$ yang digunakan untuk mengestimasi variabel laten $\xi_{b}$ dan $\eta_{i}$. Estimasi variabel laten adalah linear agregat dari indikator yang nilai bobotnya diperoleh dengan estimasi seperti dispesifikasi inner model dan outer model. Пadalah vektorvariabel independen dan $\xi$ adalah vektor variabel dependen. $\zeta$ merupakan vektor residual dan $\beta$ serta ${ }_{\Gamma}$ adalah matrik koefisien jalur (path coefficient).

\section{Operasional Variabel Variabel Endogen}

Variabel endogen ini adalah variabel yang dipengaruhi atau yang menjadi akibat,karena adanya variabel bebas (Sugiyono, 2010). Dalam penilitian ini nilai perusahaan adalah variabel endogen dan indikator yang digunakan dalam penelitian ini adalah sebagai berikut:

$$
\begin{aligned}
& \text { 1. Price Earning Ratio (PER) } \\
& \text { 2. } \\
& \text { PER }=\frac{\text { Market price per share }}{\text { Earnina per share }} \\
& =\frac{\text { Market price per share }}{\text { Book Value ner share }} \\
& \hline
\end{aligned}
$$

\section{Variabel Eksogen}

Variabel Eksogen merupakan variabel yang mempengaruhi atau menjadi sebab perubahannya atau timbulnya variabel dependen atau terikat (endogen), baik secara postifif maupun negatif, yaitu jika terdapat variabel eksogen,variabel endogen juga hadir dengan setiap unit kenaikan dalam variabel eksogen, dan terdapat pula kenaikan atau penuruan dalam variabel endogen (Sugiyono, 2010). Dalam penelitian ini terdapat tiga variabel Eksogen yaitu Intellectual Capital, Profitabilitas dan Leverage.

\section{Intellectual Capital}

Dalam penelitian ini, peneliti akan menggunakan pendekatan VAIC TM yang dirumuskan kedalam tiga indikator sebagai berikut :

1. Capital Employed Efficiency

$$
C E E=\frac{V A}{C E}
$$

Keterangan:

$\mathrm{CEE}=$ Capital Employed Efficiency

$\mathrm{CE}$ = Dana yang tersedia (jumlah ekuitas dan laba bersih)

$\mathrm{VA}=$ Value Added 
2. Human Capital Efficiency

$$
H C E=\frac{V A}{H C}
$$

Keterangan:

$\mathrm{HCE}=$ Human Capital Efficiency

$\mathrm{VA}=$ Value Added

$\mathrm{HC}=$ Gaji dan tunjangan karyawan

3. Structural Capital Efficiency

$$
S C E=\frac{S C}{V A}
$$

Keterangan:

SCE = Structural Capital Efficiency

$\mathrm{SC}=\mathrm{VA}-\mathrm{HC}$

$\mathrm{VA}=$ Value Added

\section{Profitabilitas}

Adapun indikator yang digunakan untuk profitabilitas dalam penelitian ini adalah sebagai berikut :

1. Untuk margin laba bersih

$$
N P M=\frac{\text { Laba bersih setelah pajak }}{\text { Penjualan }} \times 100 \%
$$

2. Hasil Pengembalian Total Aset (Return On Total Assets)

$$
R O A=\frac{\text { Laba bersih setelah pajak }}{\text { Total Aset }} \times 100 \%
$$

3. Hasil Pengembalian Ekuitas ( Return On Equity)

$$
R O E=\frac{\text { Laba bersih setelah pajak }}{\text { Modal Sendiri }} \times 100 \%
$$

\section{Leverage}

Adapun indikator yang digunakan untuk profitabilitas dalam penelitian ini adalah sebagai berikut :

1. Hutang terhadap Total Aset (Debt to Total Assets atau Debt Ratio)

2.

DAR $=\frac{\text { Total Hutang }}{\text { Total Aset }} \times 100 \%$ (Debt to

$$
D E R=\frac{\text { Total Hutang }}{\text { Total Modal Sendiri }} \times 100
$$

\section{Variabel Moderasi}

Menurut Sugiyono (2015:39) variabel Pemoderasi adalah variabel yang memperkuat dan memperlemah hubungan antara variabel bebas dengan variabel terikat, atau disebut dengan variabel independen kedua. Variabel Pemoderasi dalam penelitian ini adalah opini audit.

Ada lima jenis opini audit yaitu unqualified opinion, modified unqualified opinion, qualified opinion, adverse opinion dan disclaimer of opinion. Dalam penelitian ini akan menggunakan variabel dummy untuk memproksikan opini audit dengan kode 1 untuk perusahaan yang mendapatkan unqualified opinion dan kode 0 untuk perusahaan yang mendapatkan opini selain unqualified opinion (Putu Shinta dan I Gst. Ayu, 2016).

\section{Teknik Pengujian Data}

Pengolahan data dalam penelitian ini menggunakan alat analisis Structural Equation Modeling (SEM) dengan menggunakan metode alternative Partial Least Squares (PLS).

\section{HASIL DAN PEMBAHASAN}

Hasil yang diperoleh dari penelitian ini adalah sebagai berikut :

\section{Evaluasi Model Pengukuran atau Outer Model}

Evaluasi hubungan antara konstrak dengan indikatornya disebut evaluasi model pengukuran. Evaluasi ini melalui dua tahap, yaitu evaluasi terhadap Convergen Validity dan discriminan validity.

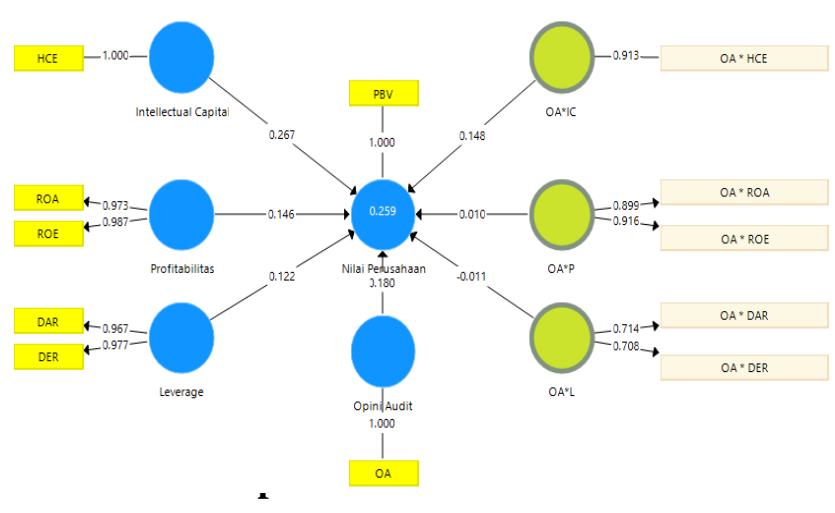

a. Evaluasi terhadap Convergen Validity

Validitas indikator dilihat dari nilai Loading Factor (LF) yang dihasilkan, nilai LF indikator $\geq 0,7$ dikatakan valid. 
Tabel.4.1

Hasil Pengujian Convergen Validity

\begin{tabular}{|l|l|r|c|}
\hline \multicolumn{1}{|c|}{ Variabel } & Indikator & $\begin{array}{c}\text { Outer } \\
\text { Loading }\end{array}$ & Ket \\
\hline $\begin{array}{l}\text { Nilai } \\
\text { Perusahaan }\end{array}$ & PBV & 1.000 & Valid \\
\hline \multirow{2}{*}{ Profitabilitas } & ROA & 0.973 & Valid \\
\cline { 2 - 4 } & ROE & 0.987 & Valid \\
\hline \multirow{2}{*}{ Leverage } & DAR & 0.967 & Valid \\
\cline { 2 - 4 } & DER & 0.977 & Valid \\
\hline $\begin{array}{l}\text { Intellectual } \\
\text { Capital }\end{array}$ & HCE & 1.000 & Valid \\
\hline Opini Audit & OA & 1.000 & Valid \\
\hline OA*IC & OA*HCE & 0.913 & Valid \\
\hline $\begin{array}{l}\text { OA* } \\
\text { Profitablitas }\end{array}$ & OA*ROA & 0.899 & Valid \\
\cline { 2 - 4 } & OA*ROE & 0.916 & Valid \\
\hline $\begin{array}{l}\text { OA* } \\
\text { Leverage }\end{array}$ & OA*DAR & 0.714 & Valid \\
\cline { 2 - 4 } & OA*DER & 0.708 & Valid \\
\hline
\end{tabular}

Sumber : Output Smart PLS

Seperti yang terlihat pada tabel 4.1 diatas menunjukan bahwa cross loading antara indikator dengan konstruknya memiliki nilai loading factor diatas 0,70 . Sehingga semua konstruk memenuhi validitas dan realibilitas. Pemeriksaan kedua dalam convergent validity adalah dengan melihat nilai cronbach's alpha dan composite reliability. Hasilnya adalah sebagai berikut :

Tabel 4.2

\section{Hasil Pemeriksaan Reliabilitas Konstruk berdasarkan Convergent Validity}

\begin{tabular}{|l|c|c|c|c|}
\hline & $\begin{array}{c}\text { Cronbach's } \\
\text { Alpha }\end{array}$ & rho_A & $\begin{array}{c}\text { Composite } \\
\text { Reliability }\end{array}$ & AVE \\
\hline $\begin{array}{l}\text { Intellectual } \\
\text { Capital }\end{array}$ & 1.000 & 1.000 & 1.000 & 1.000 \\
\hline Leverage & 0.942 & 0.966 & 0.971 & 0.945 \\
\hline $\begin{array}{l}\text { Nilai } \\
\text { Perusahaan }\end{array}$ & 1.000 & 1.000 & 1.000 & 1.000 \\
\hline OA*IC & 1.000 & 1.000 & 1.000 & 1.000 \\
\hline OA* Profit & 0.979 & 1.000 & 0.988 & 0.975 \\
\hline OA*leverage & 0.963 & 1.000 & 0.981 & 0.964 \\
\hline Opini Audit & 1.000 & 1.000 & 1.000 & 1.000 \\
\hline Profitabilitas & 0.959 & 1.047 & 0.980 & 0.960 \\
\hline
\end{tabular}

Sumber : Output Smart PLS

Nilai Cronbach's Alpha dan Composite Reliability diatas dari 0.7 menunjukan bahwa semua konstruk exsogen, endogen dan moderating semua sangat reliable. Validitas dari masing-masing nilai konstruk dapat diuji dengan average variance extracted (AVE). Konstruk dengan validitas yang baik dipersyaratkan nilai AVE harus di atas 0.50 (Ghazzali, $2014: 189$ ).
Hasil tabel diatas menunjukan nilai AVE masingmasing konstruk diatas 0.50 .

b. Discriminan validity (melihat output composit reability atau cronbach's alpha)

Untuk menguji discriminant validity adalah melihat nilai akar AVE dan membandingkannya dengan korelasi antar konstruk.

Tabel 4.3

Perbandingan AVE dengan Akar AVE

\begin{tabular}{|l|c|r|}
\hline \multicolumn{1}{|c|}{ Construct } & AVE & Akar AVE \\
\hline Intellectual Capital & 1.000 & 1.000 \\
\hline Leverage & 0.945 & 0.972 \\
\hline Nilai Perusahaan & 1.000 & 1.000 \\
\hline OA*IC & 1.000 & 1.000 \\
\hline OA*Profit & 0.975 & 0.987 \\
\hline OA*leverage & 0.964 & 0.982 \\
\hline Opini Audit & 1.000 & 1.000 \\
\hline Profitabilitas & 0.960 & 0.979 \\
\hline
\end{tabular}

Sumber : Output Smart PLS

Berdasarkan Tabel 4.3 Perbandingan AVE dengan Akar AVE dapat dijelaskan bahwa nilai Akar AVE lebih tinggi daripada korelasi antar konstruk yang lain, maka dapat disimpulkan bahwa konstruk memiliki tingkat discriminant validity yang baik.

\section{Evaluasi Model Struktural atau Inner Model}

Pada tahap evaluasi model struktural akan dianalisis dengan melihat signifikansi hubungan antar konstruk yang ditunjukkan oleh nilai $t$ statistic. Besarnya pengaruh antar konstruk dan efek interaksi (moderasi) diukur dengan nilai koefisien jalur (path coefficient). Path coeffisient yang memiliki nilai $T$ Statistic $\geq \mathbf{1 , 9 6}$ (atau dibulatkan menjadi 2) atau memiliki $\boldsymbol{P}$ Value $\leq$ 0,05 dinyatakan signifikan. Pemeriksaan ini meliputi signifikansi hubungan jalur dan nilai $\mathrm{R}$ Square $\left(R^{2}\right)$ untuk melihat hasil evaluasi model strukrual, khususnya signifikansi dari variabel moderating. Nilai $\mathrm{R}^{2}$ dapat dilihat pada tabel 4.4 untuk melihat kontribusi apakah yang diberikan variabel moderating terhadap model dapat dilihat dari efek interaksinya. 
Tabel 4.4

Nilai R Square $\left(\mathbf{R}^{2}\right)$

\begin{tabular}{|l|r|r|}
\hline & R Square & \multicolumn{1}{c|}{$\begin{array}{l}\text { R Square } \\
\text { Adjusted }\end{array}$} \\
\hline $\begin{array}{l}\text { Nilai } \\
\text { Perusahaan }\end{array}$ & 0.259 & 0.232 \\
\hline
\end{tabular}

Sumber : Output Smart PLS

Nilai $R$ Square $\left(\mathrm{R}^{2}\right)$ sebesar 0.259 berarti variabilitas konstruk nilai perusahaan dapat dijelaskan oleh konstruk intellectual capital, profitabilitas, leverage dan opini audit sebesar $25,9 \%$ sedangkan $74.1 \%$ dijelaskan oleh variabel lain yang tidak diteliti dalam penelitian ini.

\section{Tabel 4.5}

\section{Rekapitulasi Kecocokan Model (Model Fit)}

\begin{tabular}{|l|c|r|r|}
\hline & Hasil & Kriteria & Keterangan \\
\hline SRMR & 0.060 & $<0.08$ & Model fit \\
\hline NFI & 0.968 & $>0.90$ & Model fit \\
\hline rms Theta & 0.088 & $>0.12$ & Model fit \\
\hline
\end{tabular}

Sumber : Output Smart PLS

Berdasarkan Tabel 4.5 nilai SRMR sebesar 0.060 $<0.08$ artinya model dianggap cocok. Henseler dkk (2014) memperkenalkan SRMR sebagai goodness of fit measure untuk PLS-SEM yang dapat digunakan untuk menghindari model mispesifikasi. Nilai rms Theta sebesar $0.088<$ 0.12 artinya menunjukan model yang pas. Nilai RMS_theta di bawah 0,12 menunjukkan model yang pas, sedangkan nilai yang lebih tinggi menunjukkan kurangnya kesesuaian (Henseler et al., 2014).

Untuk melihat tingkat signifikansi dari pengaruh moderasi maka dilakukan bootstapping dengan hasil sebagai berikut:

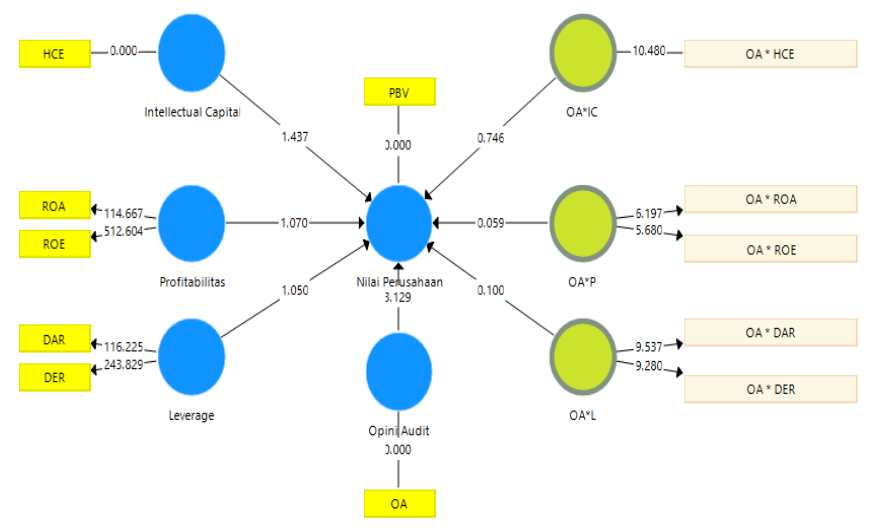

Tabel 4.6.

Nilai Path Coefficient

\begin{tabular}{|l|c|c|l|}
\hline \multicolumn{1}{|c|}{ Variabel } & t-tabel & $\begin{array}{c}\text { T } \\
\text { Statistics }\end{array}$ & \multicolumn{1}{c|}{ Ket } \\
\hline $\begin{array}{l}\text { Intellectual } \\
\text { Capital -> Nilai } \\
\text { Perusahaan }\end{array}$ & 1.96 & 1.435 & $\begin{array}{l}\text { Tidak } \\
\text { Signifikan }\end{array}$ \\
\hline $\begin{array}{l}\text { Leverage -> } \\
\text { Nilai } \\
\text { Perusahaan }\end{array}$ & 1.96 & 1.01 & $\begin{array}{l}\text { Tidak } \\
\text { Signifikan }\end{array}$ \\
\hline $\begin{array}{l}\text { OA*IC -> Nilai } \\
\text { Perusahaan }\end{array}$ & 1.96 & 0.738 & $\begin{array}{l}\text { Tidak } \\
\text { Signifikan }\end{array}$ \\
\hline $\begin{array}{l}\text { OA*Profit -> } \\
\text { Nilai } \\
\text { Perusahaan }\end{array}$ & 1.96 & 0.058 & $\begin{array}{l}\text { Tidak } \\
\text { Signifikan }\end{array}$ \\
\hline $\begin{array}{l}\text { OA*leverage - } \\
\text { > Nilai } \\
\text { Perusahaan }\end{array}$ & 1.96 & 0.101 & $\begin{array}{l}\text { Tidak } \\
\text { Signifikan }\end{array}$ \\
\hline $\begin{array}{l}\text { Opini Audit -> } \\
\text { Nilai } \\
\text { Perusahaan }\end{array}$ & 1.96 & 3.039 & Signifikan \\
\hline $\begin{array}{l}\text { Profitabilitas -> } \\
\text { Nilai } \\
\text { Perusahaan }\end{array}$ & 1.96 & 1.044 & $\begin{array}{l}\text { Tidak } \\
\text { Signifikan }\end{array}$ \\
\hline
\end{tabular}

Sumber : Output Smart PLS

\section{Interprestasi Hasil}

\section{Intellectual Capital Berpengaruh Terhadap} Nilai Perusahaan

Berdasarkan hasil perhitungan Partial Least Square (PLS) menunjukan hasil bahwa intellectual capital tidak berpengaruh signifikan terhadap nilai perusahaan. Dalam penelitian ini intellectual capital diukur dengan menggunakan model pengukuran VAIC (Value Added intellectual capital) dengan tujuan untuk menyajikan efisiensi penciptaan nilai dari aset berwujud maupun tidak berwujud yang dimiliki oleh perusahaan. Seharusnya perilaku intellectual capital ini sejalan dengan teori resource based theory atau resource based view (RBV) yang menonjolkan bahwa perusahaan sebagai kumpulan kemampuan dalam mengelola sumber daya. Hasil penelitian ini tidak sama dengan penelitian yang dilakukan Nuryaman (2015) yang menunjukan bahwa modal intelektual memiliki dampak positif terhadap nilai perusahaan. Selain itu menurut hasil penelitian Wahyu Sriastutik (2017) menunjukkan bahwa variabel intellectual capital dan ukuran 
perusahaan berpengaruh negatif terhadap nilai perusahaan. Penelitian Irina Berzkalnea dan Elvira Zelgalvea (2013) Studi ini menemukan bahwa peningkatan modal intelektual harus meningkatkan nilai perusahaan. Namun hasil empiris oleh penulis lain tidak konsisten, dan penelitian ini diperoleh hasil yang beragam juga. Ada hubungan statistik yang signifikan dan positif antara modal intelektual dan nilai perusahaan bagi perusahaan di Latvia dan Lithuania, sedangkan korelasi tersebut tidak diamati untuk perusahaan di Estonia.

Hasil penelitian ini sejalan dengan hasil penelitian Rita Wijayanti (2018) yang menunjukkan bahwa physical capital, human capital, dan structural capital masing-masing tidak berpengaruh terhadap produktivitas yang diproksikan dengan asset turnover (ATO) maupun nilai perusahaan yang diproksikan dengan Tobin"s Q. Serta hasil penelitian Rina Kurniawati (2017) yang menunjukan bahwa intensitas research and development tidak berpengaruh terhadap nilai perusahaan.

\section{Profitabilitas Berpengaruh Terhadap Nilai Perusahaan}

Berdasarkan hasil perhitungan Partial Least Square (PLS) menunjukan hasil bahwa profitabilitas tidak berpengaruh signifikan terhadap nilai perusahaan. Hasil ini menunjukan bahwa nilai profitabilitas tidak dapat mempengaruhi nilai perusahaan dimata para investor. Hal ini tdak sesuai dengan signaling teori, berdasarkan teori seharusnya profitabilitas merupakan informasi yang bisa dianggap sebagai signal bagi investor, jika sinyal tersebut baik maka investor akan tertarik untuk melakukan perdagangan saham, sehingga pasar akan bereaksi dan ada perubahan dalam volume perdagangan saham (Suwardjono, 2010). Hasil penelitian ini tidak sejalan dengan hasil penelitian yang dilakukan oleh Wahyu Sriastutik (2017) menyatakan bahwa profitabilitas berpengaruh positif terhadap nilai perusahaan, begitu juga dengan hasil penelitian Rina Kurniawati (2017) kinerja keuangan berpengaruh positif terhadap nilai perusahaan.

\section{Leverage Berpengaruh Terhadap Nilai Perusahaan}

Berdasarkan hasil perhitungan Partial Least Square (PLS) menunjukan hasil bahwa leverage tidak berpengaruh signifikan terhadap nilai perusahaan. Hasil ini menunjukan bahwa nilai leverage tidak dapat mempengaruhi nilai perusahaan dimata para investor. Hasil penelitian ini tidak sejalan dengan hasil penelitian Adesoji Adetunji, dkk (2016) yang mengungkapkan bahwa ada hubungan yang signifikan antara leverage dan nilai perusahaan dan bahwa leverage memiliki pengaruh yang signifikan terhadap nilai perusahaan. Studi ini menyimpulkan bahwa leverage adalah sumber keuangan yang lebih baik daripada ekuitas untuk perusahaan ketika ada kebutuhan untuk membiayai proyek jangka panjang.

\section{Opini Audit Berpengaruh Terhadap Nilai Perusahaan}

Berdasarkan hasil perhitungan Partial Least Square (PLS) menunjukan hasil bahwa opini audit berpengaruh positif signifikan terhadap nilai perusahaan. Dengan kata lain perusahaan yang memiliki opini audit wajar tanpa pengecualian akan memiliki nilai perusahaan yang tinggi, hal ini dikarekan informasi keuangan yang disajikan oleh perusahaan memberikan tingkat kepercayaan yang bagus menurut investor. Hasil dari penelitian ini sejalan dengan teori signaling yang mengungkapkan bahwa informasi yang dipublikasikan akan memberikan sinyal bagi investor dalam pengambilan keputusan investasi. Laporan tahunan adalah salah satu jenis informasi yang dikeluarkan oleh perusahaan dan dapat menjadi signal bagi investor atau para pihak yang berkepentingan. Dalam laporan tahunan perusahaan tercantum opini audit yang diberikan oleh auditor independen, sehingga opini tersebut dapat menjadi signal bagi pemakai laporan keuangan.

\section{Opini Audit Memoderasi Pengaruh Intellectual Capital Terhadap Nilai Perusahaan}

Berdasarkan hasil perhitungan Partial Least Square (PLS) menunjukan hasil bahwa opini audit tidak memoderasi pengaruh intellectual capital terhadap nilai perusahaan. Seharunya dengan adanya alat formal yang berupa laporan 
audit yang digunakan untuk mengkomunikasikan kesimpulan tentang laporan keuangan audit perusahaan kepada pihak-pihak yang berkepentingan bisa dijadikan sebagai salah satu instrument pendukung dalam pengambilan keputusan untuk investasi, akan tetapi dalam hasil penelitian ini menunjukan bahwa opini audit tidak memoderasi pengaruh intellectual capital terhadap nilai perusahaan dikarenakan opini audit berpengaruh langsung terhadap nilai perusahaan.

\section{Opini Audit Memoderasi Pengaruh Profitabilitas Terhadap Nilai Perusahaan}

Berdasarkan hasil perhitungan Partial Least Square (PLS) menunjukan hasil bahwa opini audit tidak memoderasi pengaruh profitabilitas terhadap nilai perusahaan. Rasio profitabilitas yang tinngi merupakan sinyal positif bagi investor dari perusahaan sehingga akan meningkatkan kepercayaan investor serta akan mempermudah manajemen perusahaan untuk menarik modal. Harusnya dengan adanya informasi tambahan dalam laporan keuangan berupa opini audit yang akan menambah tingkat kepercayaan investor terhadap kesesuain informasi keuangan yang disampaikan oleh perusahaan, maka opini audit bisa memperkuat atau memperlemah hubungan antara profiabilitas dan nilai perusahaan.Akan tetapi dalam hasil penelitian ini menunjukan bahwa opini audit tidak memoderasi pengaruh profitabilitas terhadap nilai perusahaan dikarenakan opini audit berpengaruh langsung terhadap nilai perusahaan.

\section{Opini Audit Memoderasi Pengaruh Leverage Terhadap Nilai Perusahaan}

Berdasarkan hasil perhitungan Partial Least Square (PLS) menunjukan hasil bahwa opini audit tidak memoderasi pengaruh leverage terhadap nilai perusahaan. Penggunaan hutang yang terlalu banyak tidak baik karena dikhawatirkan akan mengakibatkan penurunan laba yang diperoleh perusahaan sehingga pengelolaan leverage sangatlah penting. Nilai leverage yang semakin tinggi akan menggambarkan investasi yang dilakukan beresiko besar, sedangkan leverage yang kecil akan menunjukkan investasi yang dilakukan beresiko kecil (Analisa, 2011). Seharusnya dengan adanya laporan audit sebagai alat formal yang mengkomunikasikan tentang hasil audit atas laporan keuangan perusahaan kepada pihakpihak yang berkepentingan. Opini audit akan menambah tingkat kepercayaan investor terhadap kesesuain informasi keuangan yang disampaikan oleh perusahaan, maka opini audit bisa memperkuat atau memperlemah hubungan antara leverage dan nilai perusahaan. Akan tetapi dalam hasil penelitian ini menunjukan bahwa opini audit tidak memoderasi pengaruh leverage terhadap nilai perusahaan dikarenakan opini audit berpengaruh langsung terhadap nilai perusahaan.

\section{KESIMPULAN}

Berdasarkan hasil analisis dan pembahasan yang telah dilakukan mengenai implikasi opini audit terhadp pengaruh intellectual capital dalam nilai perusahaan didapatkan kesimpulan sebagai berikut:

1. Hasil penelitian menunjukan bahwa konstruk intellectual capital tidak berpengaruh signifikan terhadap nilai perusahaan

2. Hasil penelitian menunjukan bahwa konstruk profitabilitas tidak berpengaruh signifikan terhadap nilai perusahaan.

3. Hasil penelitian menunjukan bahwa konstruk leverage tidak berpengaruh signifikan terhadap nilai perusahaan

4. Hasil penelitian menunjukan bahwa konstruk opini audit berpengaruh positif dan signifikan terhadap nilai perusahaan.

5. Hasil penelitian menunjukan bahwa konstruk interaksi antara intellectual capital dan opini audit tidak mempengaruhi nilai perusahaan

6. Hasil penelitian menunjukan bahwa konstruk interaksi antara profitabilitas dan opini audit tidak mempengaruhi nilai perusahaan

7. Hasil penelitian menunjukan bahwa konstruk interaksi antara leverage dan opini audit tidak mempengaruhi nilai perusahaan

8. Hasil penelitian menunjukan bahwa variabilitas konstruk nilai perusahaan dapat dijelaskan oleh konstruk intellectual capital, profitabilitas, leverage dan opini audit sebesar $25,9 \%$ sedangkan $74,1 \%$ dijelaskan oleh variabel lain yang tidak diteliti dalam penelitian ini. 


\section{DAFTAR PUSTAKA}

Abdillah, Willy dan Jogiyanto Hartono. (2014). Partial Least Square ( PLS ). Yogyakarta : Andi.

Adetunji, Adesoji, Akinyemi, Abayomi, Rasheed, Olalekan. 2016. "Financial Leverage and Firm's Value: A Study of Selected Firms in Nigeria". European Journal of Research and Reflection in Management Sciences. Vol 4 No 1. ISSN 2056-5992.

Agustina, Wulan. 2007. Analisis Pengaruh Intellectual Capital Terhadap Kinerja Kantor Akuntan Publik di Surabaya. Tesis Fakultas Ekonomi Universitas Airlangga Surabaya.

Agus, R. Sartono. 2010. Manajemen Keuangan Teori dan Aplikasi. Edisi Keempat. Yogyakarta:BPFE

Akerlof, George A. 1970. The Market for 'Lemons': Quality Uncertainty and the Market Mechanism. Quarterly Journal of Economics (The MIT Press) 84 (3): 488 500

Berzkalnea, Irina dan Elvira Zelgalvea. 2013. Intellectual Capital and Company Value. Procedia - Social and Behavioral Sciences $110,887-896$.

Bontis,Nick, Wiliam Chua Chong Keow dan Stanley Richardson. 2000. Intellectual Capital and Business Performance in Malaysian Industries. Journal of Intellectual Capital. Vol 1, No. 1.

Brigham dan Ehrhardt. 2005. Financial Management Theory And Practice, Eleventh Edition. Ohio: South Western Cengage Learning.

Brigham, Eugene $F$ and Joel F.Houston. 2006. Dasar-Dasar Manajemen Keuangan. Jakarta: Salemba Empat.

Christiawan, Yulius Jogi dan Josua Tarigan. 2007. Kepemilikan Manajeral: Kebijakan Hutang, Kinerja dan Nilai Perusahaan. Jurnal Akuntansi danKeuangan, Vol. 9 No.1. Hal. 1-8. Surabaya: Universitas Kristen Petra

Fakhruddin dan Hadianto, Sopian. 2001. Perangkat dan Model Analisis Investasi di Pasar Modal, Buku satu. Jakarta: Elex Media Komputindo.
Freeman, R.E., and Reed. 1983. Stockholders and stakeholders: a new perspective on corporate governance

Friedman, Milton. 1962. Capitalism and Freedom. Chicago: University of Chicago Press

Ghozali, Imam dan Anis Chariri. 2007. Teori Akuntansi. Semarang: Badan Penerbit Universitas Diponegoro.

Ghozali, Imam. 2014. Structural Equation Modeling, Metode Alternatif dengan Partial Least Square (PLS). Edisi 4. Semarang : Badan Penerbit Universitas Diponegoro.

Gunawan, Ade dan Sri Fitri Wahyuni. 2013. Pengaruh Rasio Keuangan terhadap Pertumbuhan Laba pada Perusahaan Perdagangan di Indonesia. Jurnal Manajemen dan Bisnis Vol13 No. 012013.

Harahap, Sofyan Syafri (2015). Analisis Kritis atas Laporan Keuangan. Jakarta: PT Raja Grafindo Persada.

Harmono. 2009. Manajemen Keuangan Berbasis Balanced Scorecard (Pendekatan Teori, Kasus, dan Riset Bisnis). Jakarta: Bumi Aksara.

Ikhsan, Arfan. 2008. Akuntansi Sumber Daya Manusia. Yogyakarta: Graha Ilmu.

Kasmir. 2014. Analisis Laporan Keuangan. Edisi Satu. Cetakan Ketujuh. Jakarta : PT Raja Grafindo Persada.

Kim, Daehyun, Namil Kim dan Wonjun Kim. 2017. The Effect Of Patent Protection On firms' Market Value: The Case Of The Renewable Energy Sector. Renewable and Sustainable Energy Reviews

Kurniawati, Rina. 2017. Kinerja Keuangan Sebagai Variabel Intervening Pengaruh $R \& D$ Dan Intangible Asset Pada Nilai Perusahaan. Jurnal Ilmu dan Riset Akuntansi Volume 6, Nomor 10

Munawir, (2014). Analisa Laporan Keuangan.Yogyakarta: Liberty

Noerirawan, Ronni, dkk. 2012. Pengaruh Faktor Internal dan Eksternal Perusahaan Terhadap Nilai Perusahaan. Jurnal Akuntansi Vol.1 No. 2. hal. 4.

Nuryaman. 2015. The Influence of Intellectual Capital on The Firm's Value with The Financial Performance as Intervening 
Variabel. Procedia - Social and Behavioral Sciences Vol 211, 292 - 298.

Penrose, E. T. 1959. The Theory of the Growth of the Firm. New York: John Wiley

Pulic, Ante. 1998. Measuring the Performance of Intellectual Potential in Knowledge Economy.

Puspitasari. Maritza Ellanyndra. 2011. Pengaruh Intellectual Capital terhadap Business Performance pada Perusahaan Manufaktur. Universitas Diponegoro.

Rafika, Meidha dan Bambang Hadi Santoso. 2017. Pengaruh Keputusan Investasi, Keputusan Pendanaan, Dan Kebijakan Dividen Terhadap Nilai Perusahaan. Jurnal Ilmu dan Riset Manajemen Volume 6, Nomor 11.

Santoso, Agus. 2017. Pengaruh Good Corporate Governance Terhadap Nilai Perusahaan Dengan Kinerja Keuangan Sebagai Variabel Intervening. Prosiding Seminar Nasional dan Call For Paper Ekonomi dan Bisnis (SNAPER-EBIS 2017) - Jember. hal $67-77$

Sartono, Agus. 2010. Manajemen Keuangan Teori dan Aplikasi. Yogyakarta: BPFE.

Sawarjuwono, Tjiptohadi dan Agustine Prihatin Kadir. 2003. Intellectual Capital: Perlakuan, Pengukuran Dan Pelaporan (Sebuah Library Research). Jurnal Akuntansi \& Keuangan Vol. 5, No. 1, Mei 2003.

Spence, Michael. (1973) “Job Market Signaling”. The Quarterly Journal of Economics, 87, (

3) (Aug., 1973), pp. 355-374. The MIT Press.)

Sriastutik, Wahyu. 2017. Pengaruh Intellectual Capital, Pengungkapan Intellectual Capital dan Karakteristik Perusahaan Terhadap Nilai Perusahaan. Jurnal Ilmu dan Riset Akuntansi Volume 6, Nomor 12.

Standar Profesional Akuntan Publik - PSA 29 SA Seksi 508 (2001).

Sudana, I Made. 2011. Manajemen Keuangan Perusahaan Teori dan Praktek. Jakarta: Erlangga.

Sugiyono (2015). Metode Penelitian Kombinasi (Mix Methods). Bandung: Alfabeta.
Sujarweni, V. Wiratna. 2014. Metode Penelitian: Lengkap, Praktis, dan Mudah Dipahami. Yogyakarta: Pustaka Baru Press.

Supranto, J. 2010. Metode Ramalan Kuantitatif. Jakarta : Rineka Cipta

Ulum I. 2013. Model Pengukuran Kinerja Intellectual Capital Dengan IB-VAIC Di Perbankan Syariah. Jurnal Penelitian Sosial Keagamaan Vol. 7 No.1.

Undiyani, Putu Shinta dan I Gst. Ayu Made Asri Dwija. 2016. Opini Auditor Sebagai Pemoderasi Pengaruh Good Corporate Governance Pada Nilai Perusahaan Perbankan Tahun 2012-2014. E-Jurnal Akuntansi Universitas Udayana Vol.17.1, 29-55.

Weston, J. Fred dan Copeland, Thomas E. 2001. Manajemen Keuangan Jilid I, Edisi ke-9. Jakarta: Binarupa Aksara.

Wiagustini, Ni luh Putu. 2010. Dasar-Dasar Manajemen Keuangan. Denpasar. Udayana University Press.

Wijayanti, Rita. 2018. Pengaruh Physical Capital, Human Capital, dan Structural Capital terhadap Profitabilitas, Produktivitas, dan Nilai Perusahaan. The 7th University Research Colloqium. STIKES PKU Muhammadiyah Surakarta.

Surtikanti, S. and Saleh, D.S., 2018, November. Economic Value Added. In International Conference on Business, Economic, Social Science and Humanities (ICOBEST 2018). Atlantis Press.

Saleh, D.S., 2018. Pengaruh Operating Capacity, Arus Kas Operasi dan Biaya Variabel terhadap Financial Distress pada Perusahaan Manufaktur Subsektor Textil dan Garment yang Terdaftar di Bursa Efek Indonesia (Bei) Tahun 2009-2016. Eqien: Jurnal Ekonomi dan Bisnis, 5(1), pp.34-49.

Sukarno, U.Y., Novatiani, R.A., Yulyanti, A.A. and Djuarni, W., KESEHATAN PT. BANK DKI PERIODE 2007-2009 DENGAN MENGGUNAKAN RASIO KEUANGAN BANK DAN METODE CAMELS...... 
Sari, J.L., 2019. Analisa Kredit Modal Kerja dan Kredit Investasi Sektor Industri Kecil dan Menengah (Studi Kasus pada Pt. iks sebagai Debitur Bank Bni. Eqien, 6(1).

Nusannas, I.S., 2012. Bagaimana Harga Input dan Kuantitas Output Berpengaruh Terhadap ROE Bank (Studi kasus pada PT. Bank X). Eqien: Jurnal Ekonomi dan Bisnis, 1(2), pp.57-60.

Ma'mun, H.F. and Amruloh, D.A.G., 2019. Kreativitas dan Psychological Capital Pengusaha Batu Templek di Kabupaten Purwakarta. Eqien: Jurnal Ekonomi dan Bisnis, 6(1), pp.1-11.

Saleh, D.S., 2012. Evaluasi Peranan Leasing sebagai Salah Satu Bentuk Pembiayaan dan Pengaruhnya pada Perusahaan Daerah Air Minum (Pdam) Kabupaten Purwakarta. Eqien: Jurnal Ekonomi dan Bisnis, 1(1), pp.111.

Saleh, D.S., 2012. Evaluasi Peranan Leasing sebagai Salah Satu Bentuk Pembiayaan dan Pengaruhnya pada Perusahaan Daerah Air Minum (Pdam) Kabupaten Purwakarta. Eqien: Jurnal Ekonomi dan Bisnis, 1(1), pp.111.

Surtikanti, S. and Saleh, D.S., 2018, November. Economic Value Added. In International Conference on Business, Economic, Social Science and Humanities (ICOBEST 2018). Atlantis Press. 